\title{
Value Investing Vs. Modern Portfolio Theory
}

\section{George Athanassakos*}

The University of Western Ontario, Richard Ivey School of Business, Canada

What value investors do is not well known or understood. This is because universities have accepted the notion that markets are efficient and, as a result, teach modern portfolio theory, which cannot be more different than value investing.

Value investing is a style of investing developed in the early 30 's by Ben Graham at Columbia University [1]. It involves a three step process - even though most people believe the process is limited to only the first step. First, identify possibly undervalued stocks by choosing stocks with low price-to-earnings $(\mathrm{P} / \mathrm{E})$, price-to-book $(\mathrm{P} / \mathrm{B})$ or other valuation related metrics, second, value in depth the stocks that pass the screening process to estimate their intrinsic value and third, make an investment decision to buy only if the stock price is below the intrinsic value by a predetermined margin of safety - value investors are very careful of valuation risk, which is paying too much. Value investors are contrarian (bottom up) stock pickers with long term perspective.

Does value investing work? In answering this question, academic research focused primarily on the first step of screening as academics do not know what stocks value investors actually buy, but they do know that they tend to buy from the low $\mathrm{P} / \mathrm{E}$ or $\mathrm{P} / \mathrm{B}$ group of stocks. Such research showed that thus defined value investing works. Value stocks (low $\mathrm{P} / \mathrm{E}$ or $\mathrm{P} / \mathrm{BV}$ ) outperform growth stocks (high $\mathrm{P} / \mathrm{E}, \mathrm{P} /$ BV) in Canada, in the US and Global markets (see, for example, Basu [2], Chan, Hamao and Lakonishok (1991), Fama and French [3-5], Lakonishok, Shleifer and Vishny [6], Chan and Lakonishok [7] and Athanassakos $[8,9])$. They outperform when the markets go down and when they go up, and in good and bad times and when news is good and when it is bad. And they do all this without having higher risk, as measured by beta or standard deviation or adverse states of the world.

Other academic research, better focused on what value investors do, also showed that value investing works. Kacperczyk, Sialm and Zheng [10] and Kaperczyk and Seru [11] examined whether skilled managers exist. The researchers studied about 1,700 actively managed U.S. funds from 1984-99 and 1993-2002. They found that the more concentrated a fund was - in other words, the less diversified - the better it did. The outperformance resulted from selecting the right sectors or stocks, not from market timing. Additionally, the studies found that the lower the reliance on public information and the greater the reliance on portfolio manager's own skill, the greater the outperformance. Value investing is all about concentrating a portfolio to a few selected truly undervalued stocks. And as Keynes one said "once you attain competence, diversification is undesirable". Buffett echoes this view.

Athanassakos [12], in the first direct study of value investors, examined whether value investors add value over and above a simple rule that dictates they invest only in stocks with low $\mathrm{P} / \mathrm{E}$ and low $\mathrm{P} / \mathrm{B}$ ratios. The author found that value investors do add value, in the sense that their three-step process of selecting truly undervalued stocks produced significantly positive excess returns over and above the naive approach of simply selecting stocks with low $\mathrm{P} / \mathrm{E}$ and low $\mathrm{P} / \mathrm{B}$ ratios.

As noted investor Sir John Templeton said, "It is impossible to produce a superior performance unless you do something different from the majority" Montier [13]. Being contrarian and doing something different from the majority is precisely what value investors do.
If the evidence in favour of value investing is so overwhelming, why isn't everyone a value investor? Why does a value premium (i.e., that value, on average, beats growth investing) still exist? Shouldn't it be eliminated? Not necessarily, because the driving forces behind the value premium are human psychology and institutional biases.

Human and institutional behaviour bias stock prices in such a way that give rise to the value premium. Individuals are subject to irrational behaviour. They extrapolate, they are overly optimistic, they overreact and most importantly they herd [14]. They herd to protect their jobs. If the group loses and a portfolio manager is in the losing group, his job is protected as he lost as everyone else - but if he is wrong and others win while he loses, then his job and reputation are at stake. As john Keynes had indicated "It is better to fail conventionally than succeed unconventionally" [15].

At the same time, individuals working for institutions have their own agendas that may conflict with those of their clients or investors [16]. They act on these agendas to benefit themselves, rather than those who hired them. They rebalance their portfolios throughout the year to earn their Christmas bonus, they window dress to spruce up their portfolio to look better than they are to their clients and herd to protect their jobs [17].

Weaknesses of human nature and institutional biases are not going to go away - just as portfolio managers do poorly not due to lack of stock picking abilities, but rather due to institutional factors that encourage them to over-diversify to protect their jobs and assets under management, investors will also continue to believe the promises that growth (glamorous) stocks make, overbidding them, and giving rise to the value premium.

\section{References}

1. Graham B (2003) The Intelligent Investor. Revised Edition, Harper Collins, New York.

2. Basu S (1977) Investment Performance of Common Stocks in Relation to Their Price to earnings Ratios: A Test of the Efficient Market Hypothesis. Journal of Finance 32: 663-682.

3. Fama EF, French KR (1992) The Cross Section of Expected Stock Returns Journal of Finance 47: 427-465

4. Fama EF, French KR (1993) Common Risk Factors in the Returns on Stocks and Bonds. Journal of Financial Economics 33: 3-56.

*Corresponding author: George Athanassakos, The University of Western Ontario, Richard Ivey School of Business, Canada, Tel: 519-661-4096; Fax: 519661-3485; E-mail: gathanassakos@ivey.uwo.ca

Received April 11, 2012; Accepted April 12, 2012; Published April 16, 2012

Citation: Athanassakos G (2012) Value Investing Vs. Modern Portfolio Theory. J Bus \& Fin Aff 1:e110. doi:10.4172/bsfa.1000e110

Copyright: (c) 2012 Athanassakos G. This is an open-access article distributed under the terms of the Creative Commons Attribution License, which permits unrestricted use, distribution, and reproduction in any medium, provided the original author and source are credited. 
5. Fama EF, French KR (1998) Value versus Growth: The International Evidence. Journal of Finance 53: 1975-1999.

6. Lakonishok J, Shleifer A, Vishny RW (1994) Contrarian Investment, Extrapolation and Risk. Journal of Finance 49: 1541-1578.

7. Chan LKC, Lakonishok J (2004) Value and Growth Investing: Review and Update. Financial Analysts Journal 60: 71-84.

8. Athanassakos G (2009) Value vs. Growth Stock Returns and the Value Premium: The Canadian Experience 1985-2005. Canadian Journal of Administrative Studies 26: 109-121.

9. Athanassakos G (2011) The Performance, Pervasiveness and Determinants of Value Premium in Different US Exchanges: 1986-2006. Journal of Investment Management 9: 33-73.

10. Kacperczyk M, Sialm C, Zheng L (2005) On the Industry Concentration of Actively Managed Equity Mutual Funds. Journal of Finance 60: 1983-2011.

11. Kaperczyk MT, Seru A (2007) Fund Manager Use of Public Information: New Evidence on Managerial Skills. Journal of Finance 62: 485-528.
12. Athanassakos G (2011) Do Value Investors Add Value? Journal of Investing 20: 86-100.

13. Montier J (2009) Value Investing: Tools and Techniques for Intelligent Investment, John Wiley \& Sons, United Kingdom.

14. Scharfstein D, Stein J (1990) Herd Behaviour and Investment. The American Economic Review 80: 465-479.

15. Cassidy J (2009) How Markets Fail: The Logic of Economic Calamities.Viking Canada, Penguin Group, Toronto, Canada.

16. Greenwald BCN, Kahn J, Sonkin PD, Van Biema M (2001) Value Investing From Graham to Buffett and Beyond. Wiley Finance, John Wiley \& Sons, Inc. Hoboken, NJ, USA.

17. Athanassakos G (2008) Seasonal Patterns in Canadian Financial Markets and the Impact of Professional Portfolio Rebalancing: Evidence of Profitable Opportunities. Journal of Financial and Economic Practice 9: 73-96. 